\title{
The Evaulation of Risk Scorings in Non-variceal Upper Gastrointestinal Bleedings
}

\section{Varis Dışı Üst Gastrointestinal Kanamalarda Risk Skorlamalarının Değerlendirilmesi}

\author{
(D) Faik Özel11, (D) Elif Yorulmaz², (D Hatice Yorulmaz³, (D) Can Davutoğlu², (D Aytekin Güven1 \\ 1University of Health Sciences Turkey, İstanbul Bağcılar Training and Research Hospital, Clinic of Internal Medicine, İstanbul, Turkey \\ 2University of Health Sciences Turkey, İstanbul Bağcllar Training and Research Hospital, Clinic of Gastroenterology, İstanbul, Turkey \\ ${ }^{3}$ Haliç University Faculty of Health Sciences, Department of Nursing, İstanbul, Turkey
}

Abstract

Objective: Upper gastrointestinal (GI) bleeding is a major reason of mortality and morbidity today, and patients' follow-up and treatment costs are still high. In our study, the values of risk scorings of the patients with upper Gl bleeding in estimation of mortality and morbidity were evaluated.

Method: One hundred sixty-nine patients who were admitted to emergency internal medicine in University of Health Sciences Turkey, İstanbul Bağcılar Training and Research Hospital Clinic of Internal Medicine due to the diagnosis of upper GI bleeding were reviewed retrospectively between January 2015 and January 2016 in the study. Patients with upper Gl bleeding due to varices (esophageal and gastric) endoscopically were excluded from the study. Forrest scoring's classification was made according to the endoscopic findings. Classification of bleeding ulcers according to their appearance is as follows; Forrest 1a; "gushing active bleeding", Forrest 1b; "oozing active bleeding", Forrest 2a; "visible nonbleeding vein", Forrest 2b; "adherent clot", Forrest 2c; "flat pigmented lesion", Forrest 3; "no evidence of bleeding". Rockall scoring's classification uses clinical criteria (pulse, age, systolic blood pressure, comorbidity) in addition to endoscopic findings (diagnosis, hemorrhage). Accordingly, a score less than 3 carries good prognosis. Glasgow-Blatchford scoring's classification was calculated according to the situation of urea nitrogen, hemoglobin, systolic blood pressure, pulse, melena occurrence, syncope, and hepatic or cardiac problems. In this scoring, patients may be in the range of 0-23 points and the need for endoscopic intervention increases according to rising in the score.

Results: The average age of the participants in the study was $57.39 \pm 19.14$ years. $72 \%$ of the cases $(n=121)$ were male. While the presence of melena was observed in $88.7 \%$ of the cases, it was seen that $61.9 \%$ of the cases had peptic ulcer and $12.5 \%$ of the general surgery consultation was performed.

\section{Öz}

Amaç: Üst gastrointestinal (GiS) kanamalar günümüzde mortalite ve morbiditenin önemli bir nedenidir ve halen hastaların takip ve tedavi maliyetleri yüksektir. Bu çalışmada üst GiS kanamalı hastaların risk skorlarının mortalite ve morbidite öngörüsündeki değerliliği araştıııldı.

Yöntem: Çalışmada Ocak 2015-Ocak 2016 tarihlerinde, Sağlık Bilimleri Üniversitesi, İstanbul Bağcılar Eğitim ve Araştırma Hastanesi Iç Hastalıkları Kliniği'nin acil servisine üst GiS kanama tanısı ile gelen hastaların dosyaları retrospektif olarak incelendi. Endoskopik incelemelerde varis (özofageal ve gastrik) ile gelişen üst GiS kanaması varlığı görülen hastalar çalışmaya alınmadı. Endoskopik bulgulara göre Forrest sınıflaması yapıldı. Forrest sınıflamasında kanayan ülserler görünümlerine göre şu şekilde sınıflandırılmaktadırlar: "Forrest 1a; fışkııır tarzda aktif kanama", Forrest 1b; "Sızıntı tarzında aktif kanama", Forrest 2a; "kanamayan görünür damar", Forrest 2b; "yapışık pıhtı", Forrest 2c; "düz pigmente lezyon", Forrest 3; "kanama bulgusu yok". Rockall skorlaması sınıflandırması yaş, nabız, sistolik kan basıncı, komorbid hastalık gibi klinik kriterlerin yanında, endoskopik tanı ve hemoraji gibi endoskopi bulgularına göre hesaplandı. Buna göre üçten düşük skor iyi prognozu gösterdi. GlasgowBlatchford risk skorlama sınıflandırması üre azotu, hemoglobin, sistolik kan basıncı, nabız, melena varlığı, senkop, karaciğer hastalığının varlığı, kalp yetmezliği bulunması durumlarına göre hesaplandı. Bu skorlamada hastalar 0-23 puan aralığında olabilir ve skor artışına göre endoskopik müdahale gereksinimi de artmaktadır.

Bulgular: Çalışmaya katılanların yaş ortalaması $57,39 \pm 19,14$ yıl idi. Olguların \%72'si ( $n=121)$ erkekti. Olguların başvuruda \%88,7'sinde melena varlığı görülürken, \%61,9'unda peptik ülser, \%12,5'inde genel cerrahi konsültasyon yapıldığı görüldü. Olguların Forrest sınıfları arasında yatış süreleri, kan transfüzyonu skor ortalamaları açısından anlamlı bir farklılık bulunmadı $(p>0,05)$. Rockall ve Glasgow-Blatchford skorunun yatış

Address for Correspondence: Hatice Yorulmaz, Haliç University Faculty of Health Sciences, Department of Nursing, İstanbul, Turkey E-mail: haticeyorulmaz@hotmail.com ORCID: orcid.org/0000-0002-2429-5355 Received: 24.11.2020 Accepted: 26.04.2021

Cite this article as: Özel F, Yorulmaz E, Yorulmaz H, Davutoğlu C, Güven A. The Evaulation of Risk Scorings in Non-variceal Upper Gastrointestinal Bleedings. Bagcilar Med Bull 2021;6(2):183-189

๑) Copyright 2021 by the Health Sciences University Turkey, Bagcilar Training and Research Hospital Bagcilar Medical Bulletin published by Galenos Publishing House. 


\section{Abstract}

It was determined that there was no statistically significant difference in the Forrest classifications of the cases in terms of hospitalization duration and blood transfusion ( $p>0.05$ ). Rockall and Glasgow-Blatchford scores were statistically remarkably higher in patients with hospitalization duration, need for blood transfusion, rebleeding, intensive care follow-up, surgical intervention, and mortality $(p<0.05)$.

Conclusion: The association of Rockall and Glasgow-Blatchford risk scores with morbidity and mortality rates showed that patients should not be interpreted solely according to their endoscopic images. These scorings can be used in approach toward patients with Upper GI bleeding in comprehensive prospective studies.

Keywords: Risk assesment, risk scores, upper Gl bleeding

\section{Öz}

süresi, kan transfüzyonu intiyacı, tekrar kanama, yoğun bakım takibi, cerrahi girişim ve mortalite görülen olgularda daha yüksek değerlere sahip olduğu bulundu $(p<0,05)$.

Sonuç: Rockall ve Glasgow-Blatchford risk skorlarının morbidite ve mortalite oranları ile ilişkili olması hastaların sadece endoskopik görüntülerine göre değerlendirilmemeleri gerektiğini göstermiştir. Geniş çaplı prospektif çalışmalarda, üst Gis kanamalı hastalara yaklaşımda bu skorlamalar kullanılabilir.

Anahtar kelimeler: Risk belirlenmesi, risk skorları, üst GiS kanama

\section{Introduction}

Upper gastrointestinal (GI) bleedings occur in the lumen between the upper esophagus and ligament of Treitz (1). $85 \%$ of all GI bleedings usually arise from the upper GI (24). Peptic ulcers constitute of nearly $50 \%$ of these bleedings. $20 \%$ of peptic ulcer bleedings are severe and recurrent (5).

Upper GI bleedings constitute an important part of patients applying to surgical emergency unit. In the United States, approximately 150,000 hospitalizations occur for the assessment and treatment of ulcer bleedings every year (6). In the United Kingdom, 172 out of every 100,000 adults apply to the hospital every year due to upper GI bleeding (7). Mortality rate is around $10 \%$ despite the developing medical approaches (6). In a study, it has been revealed that hospitalization duration, endoscopic procedures and blood transfusion are among the most important reasons increasing the cost (8). Thus, there has been a tendency to putting patients into risk groups for mortality and rebleeding, based on various parameters like clinic, laboratory and endoscopic findings for years. For that purpose, various risk scoring systems that determine low and high risk patients for mortality and rebleeding and can be easily applied by clinicians in surgical emergency unit to direct the treatment of patients have been developed $(9,10)$. In the Forrest classification, bleeding ulcers are classified according to their appearances (5). The Rockall scoring is based on age, presentation with shock, comorbidities, endoscopic diagnosis and endoscopic new bleeding symptom (11). Unlike the Rockall classification, the Glasgow-Blatchford scoring (GBS) does not involve endoscopic symptoms. The Rockall system has been seen to be an accurate indicator of re-bleeding and mortality. Rockall scoring is based on age, presentation with shock, comorbidity, endoscopic diagnosis, and endoscopic evidence of new bleeding. Accordingly, patients with a score of two or less are grouped as low risk (12). Various studies have found that these scoring systems are useful for the clinician to decide on follow-up and treatment rapidly, to predict mortality and morbidity of the disease and to determine risk factors for mortality and rebleeding $(13,14)$.

The purpose of this study was to demonstrate the correlation of Rockall and GBS risk scoring, Forrest classification values and factors affecting mortality and morbidity rates in patients with upper GI bleeding.

\section{Materials and Methods}

The study was conducted with a total of 169 cases including 121 males (72\%) and 47 females (28\%), who werehospitalized in the internal medicine of emergency service of University of Health Sciences Turkey, İstanbul Bağcllar Training and Research Hospital due to the diagnosis of upper GI bleeding. The patients were evaluated retrospectively between January 2015 and January 2016. The most common signs of upper GIS bleeding are haematemesis and/or melena (1). Patients who presented to the emergency department with the complaints of black slime stool, fresh blood coming from the anus, or vomiting blood were endoscopied with a pre-diagnosis of upper GI bleeding and the findings were recorded. The patients, whose endoscopy showed upper GI bleeding due to esophageal and gastric varicose veins, were excluded from the study.

The data about the patients' age, sex, comorbidities, medications, alcohol and smoking status, hospitalization duration, need for blood transfusion, general surgical consultation, referral to intensive care, need for a surgical intervention, rebleeding and mortality were recorded. 
Urea, hemoglobin, platelet, prothrombin time, international normalized ratio, HbsAg, anti-Hbs and anti-HCV laboratory values of the patients during the application were checked. In the Forrest classification, bleeding ulcers were classified according to their appearances: Forrest la; squirting active bleeding, Forrest 1b; oozing active bleeding, Forrest 2a; non-bleeding visible vein, Forrest $2 \mathrm{~b}$; adherent clot, Forrest 2c; flat pigmented lesion, Forrest 3; ulcer with clean base, no sign of bleeding (5).

The Rockall scoring was calculated according to age, systolic blood pressure, comorbidities, endoscopic diagnosis and endoscopic new bleeding symptom. Accordingly, the patients with two or less scores were grouped as low risk (11).

The GBS is a pre-endoscopic score and includes the indicators: hemoglobin levels, urea, blood pressure, pulse, syncope, melena, and liver or cardiac problems. The GBS ranges from 0 to 23, with higher scores corresponding to increasing mortality. The GBS was showed to predict lower risk bleedings, and a GBS value of 1 or lower indicates very low risk group (12).

The connection between risk scores and hospitalization and the need for blood transfusion, in addition to assessment of rebleeding, surgical consultation, intensive care follow-up, surgical intervention and mortality rates with the Rockall and GBS, was evaluated.

\section{Statistical Analysis}

The results acquired from the study were assessed using the IBM SPSS Statistics 22. While assessing the study data, the convenience of parameters for normal distribution was assessed via the Shapiro-Wilks test. The Kruskal-Wallis test was used for intergroup comparisons of non-normally distributed parameters. The Student t-test was performed for two-group comparisons of normally distributed parameters and the Mann-Whitney U test was used for two-group comparisons of non-normally distributed parameters. The chi-square test was employed for the comparison of qualitative data. Correlations between the parameters were examined using the Pearson's and Spearman's Rho correlation analysis. The significance was assessed at the level of $\mathrm{p}<0.05$.

\section{Ethical Committee Approval}

Approval for the study was taken from the Local Ethics Committee of University of Health Sciences Turkey, İstanbul Bağcllar Training and Research Hospital Training and Research Hospital (number: 2016/454). It was conducted in accordance with the Declaration of Helsinki. Informed consent was obtained from each participant.

\section{Results}

The cases included in the study were aged between 17 and 89 years (mean $57 \pm 19$ years), male participants were aged 17-87 years (mean $54 \pm 18$ years) and female participants were aged 19-89 years (mean $66 \pm 20$ years). During the admission, $88.7 \%$ of the cases showed melena and $10.7 \%$ syncope. Table 1 shows the physical examination results of the cases during the application and the assessment of their laboratory parameters. In the upper GI endoscopy, $61.9 \%$ of the cases had peptic ulcer, $27.4 \%$ had erosive gastritis, $6.5 \%$ had cancer, $4.8 \%$ had esophagitis, and $17.9 \%$ had other lesions. The cases' hospitalization duration was 1-47 day(s) (mean 5.61 \pm 4.26 ) and blood transfusion was 0-14 unit(s) (mean 2.55 \pm 2.51 ). Surgical treatment was applied in cases where medical and endoscopic treatment methods were insufficient in upper GI bleeding and when the bleeding was accompanied by perforation, obstruction and malignancy. General surgery consultation was requested in patients whose hemoglobin level was below $8 \mathrm{~g} / \mathrm{dL}$, hemodynamic stability could not be achieved and bleeding developed for the second time despite 4-6 units of blood transfusion within 24 hours. General surgical consultation was observed in $12.5 \%$ of the cases, rebleeding in $9.5 \%$, referral to intensive care in $3 \%$, mortality in $3 \%$ and surgical intervention in $1.8 \%$ (Table 1 ).

It was determined that there was no statistically significant difference between the Forrest classifications of the cases in terms of hospitalization duration and blood transfusion, (p>0.05) (Table 2).

The cut-off values were found $<6$ for Rockall and $<11$ for GBS in this study. Score comparisons were made on the average point.

The Rockall score and GBS mean values were statistically significantly higher in the cases who had rebleeding than in the cases who did not ( $\mathrm{p}=0.008, \mathrm{p}=0.015$, respectively). The Rockall score and GBS mean values were statistically significantly higher in the cases who were referred to intensive care than in the cases who were not (respectively $\mathrm{p}=0.006, \mathrm{p}=0.002$ ) (Table 3). The Rockall score and GBS mean values were statistically significantly higher in the cases who required general surgical consultation than in the cases who did not (respectively $\mathrm{p}=0.001, \mathrm{p}=0.001$ ) (Table 3). The Rockall score and GBS mean values were statistically significantly higher in the cases who had 


\section{Table 1. Characteristics of the cases}

\begin{tabular}{|c|c|c|}
\hline & Min-max & Mean \pm SD \\
\hline \multicolumn{3}{|l|}{ Age } \\
\hline All patients & $17-89$ & $57 \pm 19$ \\
\hline Male & $17-87$ & $54 \pm 18$ \\
\hline Female & $19-89$ & $66 \pm 20$ \\
\hline Hospitalization duration (day) & $1-47$ & $5.61 \pm 4.26$ \\
\hline Blood transfusion (unit) & $0-14$ & $2.55 \pm 2.51$ \\
\hline Thrombocyte & $43,400-511,400$ & $216,402 \pm 79,271$ \\
\hline INR & $0.92-10.2$ & $1.57 \pm 1.33$ \\
\hline Hemoglobin (gr/dL) & $3.6-15$ & $8.99 \pm 2.58$ \\
\hline Urea & $16-427$ & $82.17 \pm 51.78$ \\
\hline Systolic pressure (mmHg) & $60-160$ & $108.97 \pm 16.26$ \\
\hline Diastolic pressure $(\mathrm{mmHg})$ & $40-90$ & $67.74 \pm 9.88$ \\
\hline \multirow[t]{2}{*}{ Pulse (mn) } & $70-120$ & $88 \pm 11$ \\
\hline & $\mathbf{n}$ & $\%$ \\
\hline \multirow[t]{2}{*}{ Sex } & 121 & 72 \\
\hline & 47 & 28 \\
\hline Alcohol & 3 & 1.8 \\
\hline Smoking & 60 & 35.7 \\
\hline $\begin{array}{l}\text { General surgical } \\
\text { consultation }\end{array}$ & 21 & 12.5 \\
\hline Rebleeding & 16 & 9.5 \\
\hline Referral to intensive care & 5 & 3 \\
\hline Mortality & 5 & 3 \\
\hline Surgical intervention & 3 & 1.8 \\
\hline \multicolumn{3}{|l|}{ Comorbidities } \\
\hline Total & 100 & 59.5 \\
\hline HT & 43 & 25.6 \\
\hline CHF & 41 & 24.4 \\
\hline CAD & 36 & 21.4 \\
\hline DM & 28 & 16.7 \\
\hline CRF & 18 & 10.7 \\
\hline Cancer & 11 & 6.5 \\
\hline CVD & 11 & 6.5 \\
\hline Other & 44 & 26.1 \\
\hline \multicolumn{3}{|l|}{ Medication } \\
\hline Total & 121 & 72 \\
\hline ASA & 40 & 23.8 \\
\hline NSAII & 39 & 23.2 \\
\hline Coumadin & 26 & 15.5 \\
\hline Clopidogrel & 13 & 7.7 \\
\hline Other & 42 & 25 \\
\hline
\end{tabular}

\section{Table 1. Continued}

\begin{tabular}{lll} 
& Min-max & Mean \pm SD \\
\hline \multicolumn{2}{l}{ Endoscopic pre-diagnoses lesions } & $\%$ \\
Peptic ulcer & 104 & 61.9 \\
Erosive disease & 46 & 27.4 \\
Cancer & 11 & 6.5 \\
Esophagitis & 8 & 4.8 \\
No lesions & 30 & 17.9 \\
Melena & 149 & 88.7 \\
Syncope & 18 & 10.7 \\
\hline SD: Standard deviation, INR: International normalized ratio, CHF: Congestive \\
heart failure, CAD: Coronary artery disease, CRF: Chronic renal failure, CVD: \\
Cardiovascular disease, NSAll: Non-steroidal anti-inflammatory drug
\end{tabular}

surgical intervention than in the cases who did not (respectively $\mathrm{p}=0.019, \mathrm{p}=0.001$ ) (Table 3 ). The Rockall score and GBS mean values were statistically significantly higher in the cases who had mortality than in the cases who did not (respectively $\mathrm{p}=0.010, \mathrm{p}=0.008$ ). The table shows the correlation of the Rockall and GBS with rebleeding, surgical consultation, intensive care follow-up, surgical intervention, and mortality (Table 3 ).

There was a statistically significantly positive correlation between the Rockall score and hospitalization duration at the level of $46.9 \%(\mathrm{p}=0.001)$. There was a statistically significant positive correlation between the Rockall score and blood transfusion levels at the level of $38.7 \%(\mathrm{p}=0.001)$ (Table 4).

There was a statistically significant positive correlation between the GBS and levels of hospitalization duration at the level of $36.3 \%$ ( $\mathrm{p}=0.001$ ) (Table 4 ).

A positive correlation existed between the GBS and levels of blood transfusion at the level of $50.9 \%(p=0.001)$. The table shows the correlation of the Rockall and GBS with hospitalization duration and the need for blood transfusion (Table 4).

\section{Discussion}

A great part of the patients applying to the emergency surgical units suffer from upper GI bleeding. The rate of incidence of this picture, mortality and re-bleeding rates vary. It is required that the important clinical decisions should be made quickly for a severe and life-threatening disease like acute upper GI bleeding. Risk assessment is important for upper GI bleeding; however, no score accurately predicts all important clinical outcomes (15). 
Table 2. Assessment of hospitalization duration, need for blood transfusion, in terms of Forrest classification

\begin{tabular}{lllllll} 
& F1b & F2a & F2b & F2C & F3 & p \\
\hline Hospitalization duration (day) (median) & Mean \pm SD & Mean \pm SD & Mean \pm SD & Mean \pm SD & Mean \pm SD & \\
\hline Blood transfusion (unit) (median) & $5.56 \pm 3.09(5)$ & $6.64 \pm 2.84(6)$ & $5.62 \pm 2.29(5)$ & $7 \pm 9.85(5)$ & $5.24 \pm 2.93(4)$ & 10.368 \\
\hline
\end{tabular}

'Kruskal-Wallis test, $\mathrm{p}<0.05$, F1b: Forrest 1b, F2a: Forrest 2a, F2b: Forrest 2b, F2c: Forrest 2c, F3: Forrest 3, SD: Standard deviation

Table 3. Assessment of hospitalization duration, need for blood transfusion, rebleeding, surgical consultation, intensive care follow-up, surgical intervention and mortality rates with the Rockall and Glasgow-Blatchford scores

\begin{tabular}{|c|c|c|}
\hline & Rockall score & $\begin{array}{l}\text { Glasgow- } \\
\text { Blatchford } \\
\text { score }\end{array}$ \\
\hline & $\begin{array}{l}\text { Mean } \pm \text { SD } \\
\text { (median) }\end{array}$ & Mean \pm SD \\
\hline \multicolumn{3}{|c|}{ Rebleeding } \\
\hline No & $3.86 \pm 2.35(4)$ & $11.6 \pm 3.63$ \\
\hline Yes & $5.56 \pm 2.63(6)$ & $13.88 \pm 2.36$ \\
\hline p & ${ }^{1} 0.008^{*}$ & ${ }^{2} 0.015^{*}$ \\
\hline \multicolumn{3}{|c|}{ Referral to intensive care } \\
\hline No & $3.93 \pm 2.38(4)$ & $11.67 \pm 3.49$ \\
\hline Yes & $7.2 \pm 1.92(7)$ & $16.6 \pm 3.58$ \\
\hline p & ${ }^{1} 0.006 *$ & ${ }^{2} 0.002 *$ \\
\hline \multicolumn{3}{|c|}{ General surgical consultation } \\
\hline No & $3.75 \pm 2.25(4)$ & $11.42 \pm 3.41$ \\
\hline Yes & $5.95 \pm 2.75(5)$ & $14.57 \pm 3.63$ \\
\hline p & ${ }^{10.001 *}$ & ${ }^{2} 0.001 *$ \\
\hline \multicolumn{3}{|c|}{ Surgical intervention } \\
\hline No & $3.95 \pm 2.35(4)$ & $11.69 \pm 3.49$ \\
\hline Yes & $8.33 \pm 2.89(10)$ & $18.67 \pm 2.08$ \\
\hline p & '0.019* & ${ }^{2} 0.001 *$ \\
\hline \multicolumn{3}{|c|}{ Mortality } \\
\hline No & $3.91 \pm 2.33(4)$ & $11.69 \pm 3.5$ \\
\hline Yes & $7.6 \pm 2.88(8)$ & $16 \pm 4.36$ \\
\hline $\mathbf{p}$ & $10.010 *$ & ${ }^{2} 0.008^{*}$ \\
\hline
\end{tabular}

${ }^{1}$ Mann-Whitney U test, ${ }^{2}$ Student t-test, ${ }^{*} p<0.05$, SD: Standard deviation

Table 4. Investigation of the relationship between Rockall score, Glasgow-Blatchford score and hospitalization and need for blood transfusion

\begin{tabular}{lll|l} 
& & Rockall score & $\begin{array}{l}\text { Glasgow-Blatchford } \\
\text { score }\end{array}$ \\
$\begin{array}{l}\text { Hospitalization } \\
\text { duration (day) }\end{array}$ & r & 0.469 & 0.363 \\
& p & $0.001^{* 1}$ & $0.001^{* 2}$ \\
$\begin{array}{l}\text { Blood transfusion } \\
\text { (unit) }\end{array}$ & r & 0.387 & 0.509 \\
& p & $0.001^{* 1}$ & $0.001^{* 2}$ \\
\hline
\end{tabular}

Sperman's Rho correlation analysis', Pearson's correlation analysis ${ }^{2},{ }^{*} p<0.05$
The present study revealed that the Forrest endoscopic risk classification was correlated only with general surgical consultation. It was found that the Rockall and GlasgowBlatchford score mean values were significantly correlated with hospitalization duration, need for blood transfusion, rebleeding, surgical consultation, intensive care followup, surgical intervention and mortality rates.

In their study, Güngör et al. (16), reported that the Forrest $1 \mathrm{a}$ and $1 \mathrm{~b}$ were encountered very often $(33.3 \%$ and $44.4 \%$, respectively). In the study by Önder et al. (17), it was detected that bleeding was the Forrest $1 \mathrm{a}$ at the rate of $51.5 \%$ and the Forrest $1 \mathrm{~b}$ at the rate of $24.2 \%$. They stated that it would be difficult to apply endoscopic hemostasis to these patients and even if it was applied, they would most likely need to have a surgical intervention due to higher risk of rebleeding. Thus, surgical intervention should not be delayed (17). The study by Klebl et al. (18) revealed no significant correlation between mortality, rebleeding and hospitalization for more than three days in patients with high Forrest classification (1a, 1b, 2a, 2b), either. In the present study, there were patients in the groups Forrest 1b (15.9\%), Forrest 2a (6.5\%), Forrest $2 \mathrm{~b}$ (7.6\%), Forrest 2c (11.2\%) and Forrest 3 (57.9\%) whereas there was no patient in the Forrest 1a. In the present study, no statistically significant difference was found between the Forrest groups of the cases in terms of rebleeding, referral to intensive care, surgical intervention and mortality rates. Rate of general surgical consultation was statistically significantly higher in the Forrest $1 b$ than in the other groups.

In their study, Martinez-Cara et al. (19) calculated the average hospitalization duration as 7.7 days and found a significant correlation between hospitalization duration and high Rockall and GBS. In their study, Sengupta et al. (20) indicated that hospitalization duration of $>7$ days was high risk for GBS and found that there was no statistically significant difference between patients with high risk scores and prolongation of hospitalization. In their study, Aldemir et al. (21) reported that hospitalization duration was higher in patients with high Rockall risk scores. In their study, Önder et al. (17) found no correlation between 
the Rockall risk score and hospitalization duration. In the present study, the average hospitalization duration of the cases was found to be 5.6 days. A statistically significant correlation was determined between the Rockall and GBS and hospitalization duration.

In their study, Martinez-Cara et al. (19) made blood transfusion at the rate of $62 \%$ and reported that the Rockall and Glasgow-Blatchford scorings were useful for determining the need for blood transfusion. Sengupta et al. (20) found a statistically significant correlation between high GBS and blood transfusion in their study. In the present study, the average blood transfusion was calculated to be 2.5 . There was a statistically significant correlation between the Rockall score, GBS and blood transfusion levels.

Treatment strategies in upper GI bleedings have distinctly changed over the past twenty years. Even though acid suppression treatments and endoscopic hemostasis have led to the need for a surgical intervention, mortality has still remained at the level of $6-13 \%(22,23)$. In the study by Johnston et al. (24) surgical intervention was applied to $2.1 \%$ of the patients (23). In the study by Kalkan et al. (25) $1.1 \%$ of the patients needed surgical intervention (24). In the present study, surgical intervention was applied to $1.8 \%$ of the patients.

In other studies, mortality was reported between $8 \%$ to $20.3 \%(13,17,19,20,23,25)$. In the present study, the rate of mortality was $3 \%$.

Budimir et al. (22) concluded that Rockall score was the good indicator of mortality and GBS was the good indicator of a need for blood transfusion. In the study conducted by Wang et al. (13) with 341 patients with nonvariceal upper GI bleeding, they found that a positive correlation existed between the Rockall score and rebleeding, surgical intervention and mortality. Klebl et al. (18) reported that mortality development was correlated with the Rockall score. Bryant et al. (26) determined in their study that the need for a surgical intervention and mortality risk were significantly correlated with patients whose GBS was greater than seven. They recommended early endoscopy especially for this group of patients (26). Yaka et al. (27) reported that GBS had superior sensitivity and specificity for predicting endoscopic treatment despite low positive predictive value.

In their study, Sengupta et al. (20) found a statistically significant correlation between high GBS and blood transfusion, but no significant correlation in terms of mortality. Custovic et al. (28) found that Rockall score was superior to GBS in indicating an essential for intervention as well as death rates. In the present study, it was determined that the Rockall and GBS were statistically significantly correlated with rebleeding, general surgical consultation, surgical intervention, referral to intensive care and mortality rates.

\section{Conclusion}

In the present study, the correlation of the Rockall and GBS with morbidity and mortality rates indicated that patients should not be assessed only according to their endoscopic images. It is necessary to make important clinical decisions rapidly for a serious and life-threatening disease like acute upper GI bleeding. There is a need for large-scale and comparative prospective studies to reveal the reliability of endoscopic and clinic risk scoring systems. By this way, risk scorings may come into clinical use in a more reliable way and clinicians may be able to access diagnostic and therapeutic decisions faster. In addition, risk scoring may enable to discharge low risk patients earlier and prevent a large portion of service beds from being occupied.

\section{Ethics}

Ethics Committee Approval: Approval for the study was taken from the Local Ethics Committee of University of Health Sciences Turkey, İstanbul Bağcllar Training and Research Hospital (number: 2016/454). It was conducted in accordance with the Declaration of Helsinki.

Informed Consent: Informed consent was obtained from each participant.

Peer-review: Externally peer-reviewed.

\section{Authorship Contributions}

Concept: F.Ö., E.Y., Design: F.Ö., E.Y., Data Collection or Processing: F.Ö. C.D., A.G., Literature Search: H.Y., C.D., A.G., Analysis or Interpretation: C.D., A.G., H.Y., Writing: F.̈̈., E.Y., H.Y.

Conflict of Interest: No conflict of interest was declared by the authors.

Financial Disclosure: The authors declared that this study has received no financial support.

\section{References}

1. Adler DG, Leighton JA, Davila RE, Hirota WK, Jacobson BC, Qureshi WA, et al. ASGE guideline: the role of endoscopy in 
acute non-variceal upper-GI hemorrhage. Gastrointest Endosc 2004;60(4):497-504.

2. Arlt GD, Leyh M. Incidence an pathophysiology of peptic ulcer bleeding. Langenbecks Arch Surg 2001;386(2):75-81.

3. Memişoğlu K. Acute upper gastrointestinal system bleeding. Turkiye Klinikleri J Surg Med Sci 2005;1(4):1-6.

4. Barkun A, Bardou M, Marshall JK. Consensus recommendations for managing patients with nonvariceal upper gastrointestinal bleeding. Ann Intern Med 2003;139(10):843-857.

5. Feldman M, Friedman LS, Sleisenger MH. Sleisenger \& Fordtran's Gastrointestinal and Liver Disease: pathophysiology, diagnosis, management. 7th ed. New York: Elseiver, 211-243.

6. Sung JJY. The role of acid suppression in the management and prevention of gastrointestinal hemorrhage associated with gastroduodenal ulcers. Gastroenterol Clin North Am 2003;32(3):1123.

7. Blatchford O, Murray WR, Blatchford M. A risk score to predict need for treatment for upper gastrointestinal hemorrhage. Lancet 2000;356(9238):1318-1321.

8. Campbell HE, Stokes EA, Bargo D, Logan RF, Mora A, Hodge $\mathrm{R}$, et al. Costs and quality of life associated with acute upper gastrointestinal bleeding in the UK: cohort analysis of patients in a cluster randomised trial. BMJ Open 2015;5(4):e007230.

9. Das A, Wong RCK. Prediction of outcome of acute GI hemorrhage: a review of risk scores and predictive models. Gastrointest Endosc 2004;60(1):85-93.

10. Gralnek IM. Outpatient management of low-risk nonvariceal upper GI hemorrhage. Are we ready to put evidence into practice. Gastrointest Endosc 2002;55(1):131-134.

11. Altraif I, Handoo FA, Aljumah A, Alalwan A, Dafalla M, Saeed AM, et al. Effect of erythromycin before endoscopy in patients presenting with variceal bleeding: a prospective, randomized, double-blind, placebo-controlled trial. Gastrointest Endosc 2011;73(2):245-250.

12. Imperiale TF, Birgisson S. Somatostatin or octreotide compared with $\mathrm{H} 2$ antagonists and placebo in the management of acute nonvariceal upper gastrointestinal hemorrhage: a meta-analysis. Ann Intern Med 1997;127(12):1062-1071.

13. Wang CY, Qin J, Wang J, Sun CY, Cao T, Zhu DD. Rockall score in predicting outcomes of elderly patients with acute upper gastrointestinal bleeding. World J Gastroenterol 2013;19(22):34663472 .

14. Monteiro S, Gonçalves TC, Magalhães J, Cotter J. Upper gastrointestinal bleeding risk scores: Who, when and why? World J Gastrointest Pathophysiol 2016;15(1):86-96.

15. Oakland K. Risk stratification in upper and upper and lower GI bleeding: Which scores should we use?. Best Pract Res Clin Gastroenterol 2019;42-43:101613.

16. Güngör B, Topgül K, Anadol AZ, Gök A, Kesim M. Results of emergent surgery for the upper gastrointestinal bleeding. J Exp and Clin Med 2005;22:78-84.
17. Önder A, Kapan M, Taşkesen F, Aliosmanoğlu İ, Arıkanoğlu Z, Gül $\mathrm{M}$, et al. Risk factors in non-variceal and non-malignancy upper gastrointestinal system bleedings in the patients undergoing surgery. Turkish J Surg 2011;27(4):216-221.

18. Klebl F, Bregenzer N, Schöfer L, Tamme W, Langgartner J, Schölmerich J, et al. Risk factors for mortality in severe upper gastrointestinal bleeding. Int J Colorectal Dis 2005;20(1):49-56.

19. Martínez-Cara JG, Jiménez-Rosales R, Úbeda-Muñoz M, de Hierro ML, de Teresa J, Redondo-Cerezo E. Comparison of AIMS65, Glasgow-Blatchford score, and Rockall score in a European series of patients with upper gastrointestinal bleeding: performance when predicting in-hospital and delayed mortality. United European Gastroenterol J 2016;4(3):371-379.

20. Sengupta N, Tapper EB, Patwardhan VR, Ketwaroo GA, Thaker AM, Leffler DA, et al. High Glasgow Blatchford Score at admission is associated with recurrent bleeding after discharge for patients hospitalized with upper gastrointestinal bleeding. Endoscopy 2016;48(1):9-15.

21. Aldemir M, Yılmaz G, Öztürk A. Surgical treatment in upper gastrointestinal bleeding. Cağdaş Surg J 2002;16:72-77.

22. Budimir I, Stojsavljević S, Baršić N, Bišćanin A, Mirošević G, Bohnec $\mathrm{S}$, et al. Scoring systems for peptic ulcer bleeding: Which one to use? World J Gastroenterol 2017;23(41):7450-7458.

23. Botianu A, Matei D, Tantau M, Acalovschi M. Mortality and need of surgical treatment in acu-te upper gastrointestinal bleeding: a one year study in a tertiary center with a 24 hours / day-7 days / week endoscopy call. Has anything changed? Chirurgia (Bucur) 2013;108(3):312-318.

24. Johnston MR, Murray IA, Schultz M, McLeod P, O'Donnell N, Norton $\mathrm{H}$, et al. Does preendoscopy rockall score safely identify low risk patients following upper gastrointestinal haemorrhage? Gastroenterol Res Pract 2015;2015:410702.

25. Kalkan Ç, Soykan I, Karakaya F, Tüzün A, Gençtürk ZB. Comparison of three scorıng systems for risk stratification in elderly patients with acute upper gastrointestinal bleeding. Geriatr Gerontol Int 2017;17(4):575-583.

26. Bryant RV, Kuo P, Williamson K, Yam C, Schoeman MN, Holloway RH, et al. Performance of the Glasgow-Blatchford score in predicting clinical outcomes and intervention in hospitalized patients with upper GI bleeding. Gastrointest Endosc 2013;78(4):576-583.

27. Yaka E, Yılmaz S, Doğan NÖ, Pekdemir M. Comparison of the Glasgow-Blatchford and AIMS65 scoring systems for risk stratification in upper gastrointestinal bleeding in the emergency department.Acad Emerg Med 2015;22(1):22-30.

28. Custovic N, Husic-Selimovic A, Srsen N, Prohic D. Comparison of Glasgow-blatchford score and rockall score in patients with upper gastrointestinal bleeding. Med Arch 2020;74(4):270-274 